\title{
VESTÍGIOS SUÍÇOS NA HISTÓRIA DO BRASIL.
}

CARLOS H. OBERACKER Jr.

Da Bociedade de Estudos Históricos.

O estímulo para as audaciosas expedições de descobrimento no fim do século XV e no comêço do século XVI foi a avidez das especiarias, do ouro e das pedras preciosas. Se abstrairmos o lenho que lhe deu o nome - o Brasil, descoberto em 1500 - nada disto podia oferecer aos seus descobridores; e pouco interessava os portuguêses a nova terra a não ser como base para as suas viagens às Indias. 32 anos após o descobrimento viram-se, todavia, obrigados a criar colônias na extensa costa sul-americana, caso a quisessem defender contra os seus concorrentes. Não obstante, os franceses conseguiram, em 1555, fundar uma colônia calvinista sob a proteção de Coligny e a chefia do almirante Nicolau Durand de Villegaignon na baía de Guanabara ou Rio de Janeiro. Em 1557 chegaram a esta colônia, por instâncias de seu chefe, 14 calvinistas de Genebra sob a chefia do jovem estudante de teologia Jean de Lery, os quais, após 8 meses, retiraram-se para a Europa em conseqüência de desavenças com Villegaignon. Este chegara a revogar o credo evangélico e a executar três suiços calvinistas, acusando-os de alta traição. Eram êles Jean du Bourdel, Matthieu Verneuil e Pierre Bourdon, os quais foram, em 9 de fevereiro de 1558, arremessados — de um rochedo ao mar. Hoje são considerados pelas igrejas evangélicas, como os primeiros mártires protestantes em terra brasileira. Lery que era natural da Borgonha (nascido em 1534) tornou-se cidadão de Genebra e faleceu em 1611, como pastor de L'Isl perto de Montricher no Pays de Vaud. Deixou um livro intitulado Histoire d'un voyage faict en la terre du Brésil autrement dite Amérique, valiosa fonte para os primórdios da nossa história, principalmente devido às suas observações etnológicas e às suas xilogravuras magníficas. Apareceu pela primeira vez em 1578 (editado por Antoine Chuppin, Genebra), sendo traduzido para nuitas línguas civilizadas e naturalmente também para o português (1).

(1). - Em 1580 já aparecera a 2a. ediçáo "revevée, corrigée e bien augmentée", a qual, segundo a opiníno do prof. H. Baldus, o pesquisador devia dar a preferência. Trisțo de Alencar Araripe baseou-se para a sua tradução, entretanto, na ediçáo menos fidedigna de 1878. A melhor ediçূo portuguêsa constitul a versáo de Sérglo Milliet, publicada em 1941, na "Biblioteca Histórica Braslleira", da Livraria Martins, em Săo Paulo. 
Os portuguêses que, como já foi mencionado, não toparam no Brasil com as riquezas cobiçadas, encontravam, entretanto, compensação num produto que naquela época valia ouro nos mercados europeus, o açúcar. Foi êste o produto que determinou a estruturação econômica, social e moral da sociedade colonial, que se baseava no latifúndio, na faina de escravos ou proletários agrícolas, no desprêzo ao trabalho manual, no domínio da vida política pelo senhor de engenho ou mais tarde pelo coronel, resultando daí os problemas que até hoje não conseguimos resolver satisfatòriamente. Sempre houve, todavia, estadistas e pessoas esclarecidas que, percebendo as desvantagens que tal sistema acarretava ao País, batalhavam para que fôsse, pelo menos em prte, substituído pela pequena propriedade e o trabalhador livre. $O$ primeiro entre êstes estadistas foi o conde João Maurício de Nassau-Siegen que, aliás, na juventude estudara nas universidades de Basiléia e Genebra. Quando, de 1637 a 1644, foi governador geral a serviço da Companhia holandesa das Indias Ocidentais no nosso Nordeste, isto é, precisamente naquela zona onde o problema focalizado - latifúndios e proletários agrícolas - atualmente requer solução urgente, mandava vir da Suíça três menonitas, integrantes de uma seita que se dedica por motivos religiosos à agricultura. Eram êstes menonitas o agrônomo Abrão Esaú, o técnico em pecuária Isaac Kaufmann e o inspetor de engenhos Daví Spielmann, todos do Oberland de Berna. Queria o Conde de Nassau, empregando-os em sua propriedade Bela Vista, na ilha Antônio Vaz, que abrissem novos horizontes à lavoura e pecuária de Pernambuco, complementando a monocultura da cana-de-açúcar com outras culturas e aperfeiçoando a primitiva criação de gado e técnica dos engenhos de açúcar.

Durante a época colonial houve sòmente uma única organização no Brasil que moralmente se conservou intacta, mostrando-se como destacada representante da cultura e lutando constantemente contra o sistema mencionado e suas implicações morais, principalmente contra a escravização dos índios: era a Companhia de Jesus, entre cujos membros encontravam-se muitos estrangeiros, e entre êstes alguns suíços. O Dr. Keller Aargu (2) menciona num opúsculo o jesuíta Rennward Cysat, de Lucerna, que em 1586 publicou um livro acêrca da cristianização dos índios sem, todavia, alegar se o mencionado religioso visitara o Brasil e se o referido livro refere-se exclusivamente aos índios brasileiros. $O$ padre luxemburguês J. Filipe Bettendorf elogia em sua Chronica da Missão da Companhia de Jesus

(2) - - Keller-Aargau, Ständerat Dr. Gottfried, Das Auswanderungsproblem in der Schweiz mit besonderer Beruecksichtigung von Brasilien. Bericht, erstattet in der Staenderatssitzung vom 7.-8. Januar 1936. Mit e Inlgen historischen Anhaengen. Druck, u. Verlag E. Loepfe-Benz, Rorschach. 1936. 
no Maranhão a obra missionária do suíço Jodocus Perret a quem no Brasil chamavam Peres (nascido em 1633 em Friburgo e falecido em 1707 em Belém), e o qual para citar as palavras de Bettendorf era "homem de grande saber e virtude". Fôra antes de chegar à Bahia professor de filosofia nas Universidades de Munique e de Dillingen, na Baviera. As suas doutrinas não parecem ter agradado muito aos seus superiores em Salvador. Transferido para o Maranhão trabalhou no início como simples missionário, fundando a primeira estação missionária na embocadura do Amazonas, a de Jaboaquara. Posteriormente deu, como superior, professor e reitor, grande impulso à evolução dos colégios e cursos humanistas dos jesuítas em São Luís e Belém assim como à missão entre o índios, avançando com as reduções até o Rio Madeira (3), Rio Negro e a região do Amapá. A missão, iniciada por sua iniciativa e durante o seu superiorato no Amapá pelo missionário e cartógrafo alemão Aloísio Conrado Pfeil, de Constança, viria fundamentar as reivindicações de Portugal e mais tarde do Brasil sôbre aquêle território, visto que o mesmo missionário deixou vários mapas em que se apoiaria o Barão do Rio Branco para assegurar pertencer êste território ao Brasil contra as pretensões da França .

Entre os jesuítas que trabalhavam no Sul do atual Brasil e na região que então pertencia ao assim chamado Estado dos Jesuítas no Rio Paraguai, sob o patrocínio dos espanhóis, encontravam-se entre outros os padres suíços Pe. Jodoco Bachmann, de Luzerna, Pe. Antônio Betschon (1687-1748), de Aargau, e o chefe-organizador da economia do "Estado Jesuítico", o cartógrafo Pe. Karl Rechberg (nascido em Altdorf, 1688, cantão de Uri). Um helvético de conhecimentos multiformes era o padre Martinho Schmid, nascido em 1694 na cidade de $\mathrm{Zug}$, que instruiu os indígenas na tecelagem, pintura, escultura e fabricação de instrumentos musicais. Construiu, aliás o primeiro órgão nas Missões, fundiu os primeiros sinos e destacou-se como mestre-relojoeiro e arquiteto. Foi ainda geógrafo e astrônomo, mandando vir da Europa um telescópio e outros instrumentos astronômicos. Deu, como muitos outros jesuítas, exemplo magnífico de como se podia ter espalhado a cultura cristã entre os nossos desdenhados e primitivos aborígines sem destruir-lhes a base cultural e a língua da cultura original.

Estadista de envergadura, que após Maurício de Nassau tentou contrabalançar o sistema colonial baseado no latifúndio e na escravidão, foi o Marquês de Pombal. Tudo indica, aliás, que foi êle quem introduziu no Brasil aquêle sistema de colonização oficial e

(3). - Junto aos indios irurizes. 
estadual, pelo qual se localizava colonos casados ou com famílias em determinadas áreas divididas em propriedades "relativamente" pequenas, com a condição de serem trabalhadas pelos próprios proprietários e a sua família (sem escravos portanto). Estas colônias ficavam sob uma administração especial até que alcançassem certo desenvolvimento que permitisse a sua emancipação, com a criação de um nôvo município ou com a sua inclusão na administração do respectivo município em que se situavam. Fundaram-se na época pombalina numerosas colônias agrícolas dêste tipo, tanto no Sul quanto no Norte, enviando o govêrno de preferência casais açorianos ou também soldados demitidos ou banidos e casados com mulheres necessitadas ou oriundas dos presídios portuguêses. Entre os muitos soldados que se localizaram no baixo Amazonas, encontraram-se não poucos mercenários estrangeiros e entre êstes numerosos suíços, cujos nomes em parte conhecemos (4). Em todo o caso os suíços tanto se destacaram entre os soldados estrangeiros que o historiador Ferreira fala até de uma colônia suíça que, em 1765. sob o nome de Vila Viçosa de Madre de Deus, estabeleceu-se no Uanarapecú, um dos afluentes do nosso rio-mar. Esta colônia, entretanto, desapareceu como tôdas as outras que Pombal mandou fundar, pois o trabalho livre do homem branco não podia vingar num meio que o hostilizava e desprezava.

50 anos mais tarde outra tentativa foi feita, com o mesmo sistema, por D. João VI e continuada, aliás com êxito, por D. Pedro I. Em 1819 D. João fundou a primeira colônia baseada realmente na pequena propriedade agrícola e no trabalho livre do imigrante estrangeiro e branco. Era a colônia de Nova Friburgo, perto do Rio, na Serra dos Órgãos. Os colonos eram suíços, em parte naturais do cantão de Friburgo ( 873 dos 2.003 imigrantes), enquanto que os restantes vieram dos cantões do Valais, Vaud, Solothurn, Berna, Lucerna e Aargau. A colônia devia servir de estimulante exemplo ou seja de escola à população nativa no campo da agricultura e principalmente da pecuária, isto é, da produção de leite e de laticínios, idéia que então prevalecia. Ainda 1835 o Visconde de Caravelas encarregava por exemplo o representante brasileiro em Londres de mandar

\footnotetext{
"dois casais suiços hábeis para o ensino e prática no Brasil de todos os métodos agrícolas, empregados nas fazendas normais de Fellenberg" (5).
}

(4). - Cf. Oberacker, Carlos H., Deutsche Kolonisten z.Z. Pombals im AmazonasTal (Colonos alemáes ao tempo de Pombal no Vale do Amazonas), manuscrito.

(5).- Aguiar (Antônio Augusto de), Vida do Marquez de Barbacena, Imprensa Nacional, Rio de Janeiro, 1896, pág. 891. 
A colônia Suíça de Nova Fribúrgo, infelizmente, fracassou, e isto por dois motivos; primeiro, devido ao terreno muito acidentado e pouco apropriado para a agricultura e segundo devido à má escôlha dos emigrantes, aproveitando as comunas suíças a oportunidade de se livrar de gente necessitada que thes pesava no orçamento. A maioria dos colonos se transferiu para a capital, onde os antífices fàcilmente progrediram, enquanto que os outros se alistaram nos batalhões estrangeiros, chegando as famílias muitas vêzes à extrema miséria. Aliás, constituiam êles o núcleo da guarda de segurança pessoal de D. Pedro I e os primeiros soldados dos afamados corpos estrangeiros que o imperador formara para a defesa da independência brasileira e reconquista das províncias do Norte, fiéis às côrtes e a Portugal (6). Os colonos retirantes foram substituídos por alemães, engajados pelo Major von Schaeffer, mas a colônia como centro agrícola nunca progrediu, permanecendo, entretanto, a localidade de Nova Friburgo que constitui hoje uma famosa cidade balneária $e$ centro da indústria de passamanes. Aliás, na mesma época em que vieram os colonos de Nova Friburgo, estabeleceram-se outros suíços no Sul da Bahia, nas colônias Leopoldina e Frankental, fundadas por Freyreiss e Schaeffer respectivamente. Estas colônias baseavam-se todavia no trabalho do escravo africano; o mérito dêstes colonos, chamados os solitários de Almada, e os quais em parte eram suíços, foi o de terem começado a cultivar o cacau em grandes plantações, dando neste campo exemplo e transformando o produto - que se propagou pelos municípios vizinhos de Ilhéus - numa das primeiras riquezas daquele Estado e de todo o Brasil. Mais tarde, a firma suíça Wildberger \& Co, em Salvador, fundada em 1829 sob a razão de Irmãos Jezler \& Trumpy, por intermédio de suas fazendas-modêlo Boa Sentença e Helvetia, deu grande impulso à evolução e racionalização da cultura do cacau, assim como à sua exportação. Ainda na mesma época encontravam-se suíços entre os pioneiros do café nos arredores do Rio, e em São Paulo o brigadeiro José Jacob Baumann, de origem suíça, em sua chácara cultivava árvores frutíferas, videiras, flôres e hortaliças européias, aclimatando-as e propagando-as.

Entre os colonos alemães que nas décadas seguintes se estabeleceram nos três Estados sulinos, assim como em São Paulo, Minas, Rio de Janeiro e Espírito Santo, sempre havia também alguns suíços que, entretanto, misturavam-se com os outros imigrantes não deixando vestígios na maioria dos casos. Encontramos, naturalmente, suíços espalhados por todos os recantos do vasto Brasil. A Caritas Suíça calculou em 1936 as famílias suíças imigrados no Brasil em 2.800,

(6). - Weech, op. cit., pág. 31. 
algarismo êste que deve ficar muito abaixo da realidade. As colônias baseadas na pequena propriedade agrícola, tiveram uma notável porcentagem de suíços; fundadas por êstes foram: no Rio Grande do Sul - Roca Sales, no rio Taquarí, e Santa Maria ou Nossa Senhora da Soledade, no município de Montenegro, onde nas picadas Schweizertal, Santa Luísa e Santa Clara em 1866 se estabeleceram alguns colonos de Vouvry no Cantão Valais (7). Em Santa Catarina existiam a localidade de Nova Zurique (1903), posteriormente denominada Nova Breslau e hoje Presidente Getúlio, Nova Helvetia (ou Vencida) no vale do ribeirão do Ferro, no município Ibirama. A colônia que mais se vangloria no sul do País, de uma considerável porcentagem de imigrantes suíços, é a antiga colônia D. Francisca, o atual município de Joinville, cuja sede por causa de sua rápida industrialização é chamada a Manchester catarinense. Joinville constitui ao lado de Blumenau a mais bem sucedida colônia alemã em Santa Catarina e é uma comuna modêlo na qual os descendentes suíços (os Colin, Richlin etc.) desempenharam até esta data um papel de destaque. Logo no início da colonização, suíços, aliás de pouco recursos, estabeleceram-se ao Oeste da sede da colônia, na chamada Estrada dos Suíços, fundando êles, em 1856, até uma sociedade cultural e de mútuo socôrro denominada Helvetia (8).

Entre as 145 famílias de colonos, em parte retirantes de Joinville, que se estabeleceram nos anos de 1825 a $1871 \mathrm{em}$ redor da capital do Estado do Paraná, havia também suíços. No século em curso, em 1915, fundou-se em Curitiba a "Sociedade de Auxílio Mútuo Helvetia" que, em 1929, contava com 75 sócios. Em 1852 instalou-se numa ilha da baía de Paranaguá o suíço Charles Perret Gentil, para fundar a colônia de Superaguí, atraindo outros conterrâneos da Europa e parceristas das fazendas paulistas. Outro suíço, J. L. Moré, escreveu acêrca dêste empreendimento, com fins de propaganda, o opúsculo Le Brésil em 1852 et la colonisation future. Outra brochura de caráter idêntico escreveu para atrair os seus compatriotas ao Brasil o suíço Pradez. Em 1869 surgiu perto de Curitiba a colônia Argelina, entre cujos colonos se encontravam alguns helvéticos. Em 1908 foi fundada aí também a colônia Afonso Pena com 20 famílias suíças, depois substituídas por poloneses. Em 1935 emigraram umas 36 famílias suíças para o Norte do Paraná, zona que se desenvolveria em estilo americano, e em 1952 formou-se no município de Guarapuava, com auxílio do govêrno suíço, a grande e hoje florescente colônia agrícola com cinco aldeias e 2.500 colonos de origem alemã e naturais do Banat nos Balcãs. No Estado do Rio

(7). - Em 1875 contavam-se aí 48 súços. 
existiu, cêrca de 1890 e perto de Teresópolis, a colônia hoje desaparecida, de Alpina, que fundada pelo suíço Eugênio Meyer; em 1908, surgiu nas proximidades de Rezende a colônia Visconde da Mauá ou Itatiaia, mais tarde também abandonada pelos seus fundadores, com 80 famílias de Graenichen e Laufenburg (Cantão Aargau), e outras do cantão de Zurique. Em Minas Gerais estabeleceram-se colonos suíços em Itajubá, e no Espírito Santo apareceram colonos helvéticos nas colônias de Santa Isabel (8 pessoas), Santa Leopoldina (104 pessoas) e gente de Aargau e Schwyz no Vale 25 de Julho.

O Estado brasileiro que mais lucrou com a imigração suíça foi, todavia, São Paulo, para onde desde os meados do século passado vieram alguns milhares de suíços, não como colonos a serem localizados em núcleos baseados na pequena propriedade agrícola, mas como trabalhadores contratados para as fazendas de café, seduzidos pelos agentes de uma firma do Senador Vergueiro que os mandava vir para que substituíssem os escravos africanos cuja importação fôra suprimida. O sistema aplicado era o da parceria, pelo qual o fazendeiro deixava à disposição do imigrante certa área cuja safra se dividia pela metade entre o assim chamado colono e o latifundiário. O colono tinha, entretanto, que reembolsar todos os gastos de viagem e transporte; ficando desde logo prêso ao fazendeiro que lhe adiantava ainda os mantimentos e outros artigos até que pudesse iniciar o resgate pela entrega da primeira safra. No caso de surgirem doenças, ou de famílias com numerosas crianças pequenas ou ainda no caso de fracasso do próprio colono devido à situação estranha em que se via colocado, de má vontade ou até fraude do fazendeiro escravagista, o imigrante tornava-se pràticamente escravo, ou pelo menos dependente por muitos anos. O Dr. Weizinger menciona como exemplo o caso da família von Zuben que em vez de quatro anos, como calculara, devia trabalhar 17 anos para se tornar livre, e era êste não um caso excepcional, pois tinha um patrão bom e compreensivo. A situação deplorável em que muitos dos parceiristas ficavam, deu ensejo para uma propaganda contra a emigração para o Brasil ną Europa. $O$ professor Thomas Davatz que emigrara sob êste sistema escreveu um livro Die Behandlung der Kolonisten in der Provinz São Paulo (Chur, 1858) que devido ao seu valor para o conhecimento das condições do trabalhador agrícola no século passado mereceu ser traduzido sob o título Memórias de um colono no Brasil pelo maior historiador atual no Brasil, Sérgio Buarque de Holanda (Livraria Martins,

(8) . - Em Santa Catarina existia também uma colônia chamada Lucerne ou Luzerna, hoje Bom Retiro, na Estrada de Ferro Rio Grande-São Paulo, mas náo sabemos se êste nome se refere à cidade súça ou ao alfafa que talvez se plantava ai. 
São Paulo, 1940). Do mesmo tema trata também a obra notável do naturalista e ministro suíço, enviado especialmente para estudar a situação dos imigrantes, João Jacó Tschudi (9) de Glarus, "Reisen in Suedamerika" (5 tomos, Brockhaus, Lípsia, 1866 e 1869), obra que também foi publicada em portguês pelo Instituto Nacional do Livro, por ser considerado fonte valiosa para o estudo das condições políticas, sociais, econômicas e culturais da época.

Muitos dos parceiristas que vieram nos anos de 1854 até o fim do império, em 1889, eram naturais dos cantões de Unterwalden, Aargau e Berna. Sòmente nas fazendas de café da província de São Paulo surgiam então umas 24 colônias de parceria. Muitas dessas famílias suíças se retiraram posteriormente para as cidades ou vilas paulistas, onde se mesclaram com a população local. Outros colonos fizeram tentativas sem êxito de se estabelecerem em colônias baseadas na pequena propriedade agrícola, assim por exemplo perto de Ubatuba e Cananéia na costa paulista, na colônia de Rio Nôvo e em outras no Espírito Santo. A colônia mais bem sucedida, não sòmente das fundadas por parceiristas suíços, mas de tôdas as colônias suí§̧as, é a colônia Helvetia perto de Campinas, na qual se fixaram desde 1888 tamílias suíças, quase tôdas oriundas de Obwalden e emigradas de 1854 a 1887; esta notável obra colonizadora que em 1936 abrangia perto de 5.000 hectares e 2.200 pessoas e a vida social dos colonos foi pormenorizadamente descrita por ocasião de seu cínqüentenário, em 1935, pelo Dr. Francisco Weizinger (10). Uma filial, por assim dizer, dêste estabelecimento constitui a colônia Nova Suíça, perto da cidade de Piracicaba, fundada por nove famílias de Helvetia. Estas colônias conservaram até hoje certos traços do folclore suíço, assim por exemplo o dialeto e a Sociedade de Tiro ao Alvo com o Guempelschiessen. - Ainda no Estado de São Paulo fundou, em 1898,

\footnotetext{
(9). - Tschudi processou em 1861 a firma de Verguelro por ter faltado com os seus compromissos para com as comunas suiças que, em parte, financiaram a emigração, exigindo Fr. 227.982.-. O processo se arrastou por anos até que verguetro declarou, em 1869, a sua insolvência (v. Keller- Aargau, pág. 26). Mui ao contrário do que se tem afirmado, o senador náo parece ter sico pessoa domínada por grandes escrúpulos. Confirma-o não sòmente o levante dos colonos na sua fazenda (cf. Davatz), mas também a clrcunstância pouca conhecida de que êle, admitindo a insustentabilidade da escravatura, propôs em 1830 projeto de lei para o regulamento do trabalho agrícola "que pouco mais era do que uma escravidão disfarçada", "tăo impertinentes e duras eram as intervençóes da polícla e da cadela nas menores infracçōes dos acordos assinados" (Calógeras, Formaçâo Historica do Brasil, 3a. edição, Companhia Editôra Nacional, São Paulo, 1938, pág. 141).

(10). - Colônia Helvetia no Brasil, 1835-1935, com 165 retratos em autotipla, 6 tabelas genealógicas e 1 mapa, Escolas Profissionals Saleslanas, Såo Paulo, 1935 (em português e alemáo).
} 
o professor suíço do curso secundário Johann Keller com 11 famílias helvéticas a colônia de Funil que posteriormente foi denominada Núcleo Campos Sales e hoje Cosmópolis. Tôdas estas colônias suíças, assim como os muitos lavradores individuais da Suíça com suas chácaras e fazendas espalhadas por todos os recantos do País, - mesmo os que em parte fracassadas por motivos de fôrça maior - contribuiram da mesma maneira como os emigrantes de outras nacionalidades para superar o desprêzo com que foi considerado o trabalho do homem branco e livre no Brasil. Introduziram nova moral de trabalho, dignificaram e valorizaram ao mesmo tempo o homem africano, preparando a sua libertação.

Nesta altura devemos mencionar duas outras personalidades suíças: Max Wirth (1881-1952) e o padre jesuíta Theodor Amstad (1851-1938) de Beckenried, no cantão de Unterwalden. Max Wirth era ao lado do rei do café, o alemão Francisco Schmidt, um dos mais notáveis pioneiros do café no Brasil, pois desbravou a fértil região da Estrada de Ferro Paulista para a cultura da rubiácea e era ainda um dos primeiros fazendeiros que fudaram no Nortc do Paraná extensa fazenda de café. Além disso, Max Wirth foi o fundador da cidade de Osvaldo Cruz na Estrada de Ferro Paulista. O padre Amstad S. J. granjeou grandes méritos em relação ao desenvolvimento da lavoura baseada na pequena propriedade agrícola no Estado do Rio Grande do Sul. Emigrara em 1885, e como cura de almas na zona de colonização alemã, compreendeu dentro em breve que a missão do pequeno agricultor no Brasil exigiria a sua organização e a aplicação da idéia do cooperativismo. Foi êle quem propagou primeiro o cooperativismo no Brasil, elaborando em 1903 diretrizes para a constituição de cooperativas, fornecendo ainda modelos e projetos de estatutos, de balanços e para a prestação de contas, antes que o próprio govêrno baixasse a respectiva legislação, em 1907. Já em 1901 fundou-se, por iniciativa sua, em Nova Petrópolis a primeira caixa Raiffeisen, isto é de depósito e empréstimo na base cooperativista. Uma das caixas fundadas por êle chegou a transformar-se no importante Banco Agrícola Mercantil S. A. Em 1925 fundiram-se as caixas Raiffeisen do Rio Grande do Sul na "Central das Caixas Rurais", da qual, nos meados do século, quase cincoenta cooperativas faziam parte. Ao padre Amstad deve o Rio Grande do Sul ainda o impulso para as hoje tão importantes cooperativas de vinicultores e de laticínios. Em 1941, isto é, três anos após a morte do pioneiro, já existiam 339 cooperativas sòmente naquele Estado brasileiro. Juntamente com outros jesuitas, Amstad fundou e organizou também a primeira Liga de Lavradores com a finalidade de prestar assistência econômica, social e cultural aos colonos. Como então não havia possibilidade de 
uma organização que não se baseasse na confissão religiosa, transformou a Liga, - tomando o modêlo suíço como exemplo - na União Popular dos Católicos de Língua Alemã que existe ainda hoje e a qual desempenhou um papel benéfico, principalmente no campo de colonização e de educação dos descendentes de alemães. O padre Amstad é ainda o autor de preciosa fonte sôbre a imigração alemã no Rio Grande do Sul, do livro "Hundert Jahre Deutschtum in Rio Grande do Sul, 1824-1924" (Cem anos de germanidade no Rio Grande do Sul, 1824-1924), editado pela União das Sociedades Alemãs, em 1924 (Tipografia do Centro, Pôrto Alegre, 1924) e de muitos outros importantes estudos sôbre o mesmo assunto. Aliás, em São Paulo houve outro suíço que mais tarde propagou a idéia do cooperativismo; trata-se do mencionado fundador de Cosmópolis, o prof. Johann Keller, que em 1929 organizou a Cooperativa Agrícola Teuto-Brasileira que tantos serviços pertsou aos sitiantes e chacareiros de língua alemã naquele Estado.

Entre os sacerdotes houve sempre não poucos helvéticos; dos pastores protestantes mencionamos os nomes Dietschi e Buchli. Entre os missionários católicos no vale do Amazonas encontramos em tempos mais recentes o padre Marcos Schawalder natural de Widnau no Cantão São Gal o qual, em 1929, fundou as importantes missões do Rio Xingú. Já antes dêle, em 1872, o capuchinho Cândido de Heremonce, - mais tarde assassinado pelos gentios - iniciou na confluência dos rios Surubijú e Ararandem a missão de São Fidelis. Como educadores da mocidade destacaram-se nesta zona, em Altamira, no Xingú, o padre Guilherme Keel, de Rebstein no Cantão São Gal, e o padre João Zemp natural de Entlebuch, como diretor do seminário de rapazes.

- Entre os professôres leigos deve ser citado o já mencionado Johann Keller que em São Paulo desempenhou papel notável como pedagogo. Como professor notável que viveu no Rio de Janeiro que escreveu uma boa gramática da Língua portuguêsa, o Visconde de Taunay designa Charles Adrien Grivet (1816-1876). Aliás, não devemos nos esquecer que os princípios progressistas de pedagogia de Pestalozzi e Fellenberg cêdo encontraram resonância no Brasil, onde já em 1854 fôra abolido o castigo corporal nas escolas. Um dos maiores entre os pedagogos helvéticos era sem dúvida o professor catedrático da Faculdade Politécnica de São Paulo, Roberto Mange (1885-1955) que nasceu em La Tour-de-Peilz no cantão de Vaud. Foi êle a quem deram o cognome de "Pestalozzi brasileiro" por ser o fundador do SENAI (Serviço Nacional de Aprendizagem Industrial), instituição esta que trouxe tão dicisivos benefícios para a nossa evolução industrial em consequiência dos milhares de trabalhadores espe- 
cializados que formou em todo o País. Em outro setor importante da educação de técnicos, como se constitui a formação de agrônomos, destacaram-se o professor de agronomia e botânica, Dr. Karl Glasl, contratado em 1863 para dirigir a Escola de Agronomia e uma fazenda-modêlo anexos ao Jardim Botânico de Rio, cujo diretor se tornária mais tarde. Andreas Goeldi, presumivelmente um parente de outro Goeldi que ainda mencionaremos, dirigiu mais tarde, no primeiro decênio dêste século, uma estação experimental em Igarapé-Açú no Pará, e Jacques Schendler, outro agrônomo, o primeiro diretor da Escola Agrícola em Juiz de Fora. Dos jornalistas mencionaremos ùnicamente $\mathrm{A}$. Otto Uhle, fundador e editor do conhecido almanque Uhle-Kalender e de muitas outras obras de grande proveito e valor para os imigrantes.

Como já foi mencionado, os colonos suíços, como os de outra procedência, não deviam dar sòmente nôvo estímulo ao desenvolvimento da agricultura, mas também ao artezanato e à pequena indústria . E' o que provam os contratos que obrigavam os artesãos suíços que vieram para Nova Friburgo

"a ensinar os nacionais que quisessem aprender" (11).

E de fato, uma série de vilas e cidades lucrou com os imigrantes suíços e os retirantes das fazendas e colônias agrícolas. Entre estas localidades que foram favorecidas pelo trabalho dos artezãos suíços encontram-se preferencialmente Joinville, Curitiba, São Paulo, Campinas, Jundiaí e o Rio de Janeiro. Mencionemos alguns exemplos. Em Curitiba Gottlieb Mueller de Unterkulm, no Aargau, fundou com os seus cinco filhos uma das mais importantes fundições e fábricas de máquinas no Sul do País; em São Paulo, as firmas J. Schmuziger e Honegger desempenham papel de destaque no campo da fabricação de máquinas texteis e os respectivos acessórios; em Piracicaba, Peter Kraehenbuehl já em 1870 fundou uma mecânica para a fabricação de todos os tipos de carruagens e outros artigos. No Rio, onde os ex-colonos artezãos de Nova Friburgo deram impulso à evolução industrial, o engenheiro José Villiger fundou em 1888 a Cervejaria Brahma, hoje ao lado da Antártica, o maior truste para a fabricação de cerveja e outras bebidas e espalhado por todo o país. Em Salvador na Bahia, a firma Meuron \& Cia de François de Meuron de Neuchâtel começou em 1816 com a produção e exportação de rapé. Sob a direção técnica de José Gerspacher de Aeschi (nascido em 1865 no cantão de Berna), Amaro da Silveira e Carlos Wigg construiram, em 1888, na localidade Esperança, perto de Itabira do Campo,

(11). - L. G. dos Santos, Memórias, pág. 702. 
em Minas Gerais, um alto forno, e cinco anos mais tarde outro em Miguel Burnier (São Julião), sendo desta maneira considerados os pioneiros da moderna indústria pesada brasileira.

Nesta altura não queremos esquecer de mencionar o papel destacado e importante que desempenharam no Brasil as grandes firmas suíças de projeção internacional como Geigy, Ciba, Nestlé, Sandoz, Schindler, Brown-Boveri, Sulzei, Indústrias Químicas de Basiléia e outras mais .

Além do artezanato e da indústria, os suíços fomentaram o comércio. As relações comerciais são até mais antigas do que a independência brasileira. Na biblioteca central de Zurique existe um diário (11a) interessante de dois comerciantes suíços, Haans Gaspar Zoller e Hans Felix Escher, os quais já no ano de 1597 viajaram para o Brasil.

$\mathrm{Na}$ Bahia, em Salvador, a firma Meuron \& Cia começou em 1816 a exportar o tabaco e a firma antecessora de Wildberger \& Co o cacau. Também no Rio de Janeiro havia naquela época comerciantes suíços, como João Martinho Flach, natural de Schaffhausen, confidente e amigo altruista da imperatriz D. Leopoldina, e outros. Entre os fundadores do mais antigo Clube recreativo no Brasil, a Germânia (fundado em 7-8-1821), encontravam-se dois suíços, e em 1825 havia cinco associados helvéticos. Pierre Schmittmeyer fundou no mesmo ano o Schweizerischen Huelfsverein para socorrer os colonos de Nova Friburgo. Hoje existem tanto no Rio de Janeiro como em São Paulo duas Maisons Suisses com clube ginástico, mútuo socôrro, cantores, cercle suisse, etc. Das 4.500 pessoas suíças registradas pelas representações diplomáticas em 1934 a maioria encontrar-se nestas duas cidades principais do Brasil, onde se dedicam em primeiro lugar ao comércio, principalmente ao da importação e exportação, vendendo relógios, máquinas, peças sobressalentes, etc. e comprando café, peles, óleos vegetais etc. . Mas também havia, já no século passado considerável participação de suíços no comércio interno.

Há ainda dois outros setores em que suíços se destacaram: o campo militar e o científico e artístico. O primeiro oficial suíço que encontramos nas páginas da nossa história é João Bartolomeu Havelli, integrante da comissão de oficiais portuguêses e estrangeiros que, após o tratado de Madrid, em 1750, devia fixar os limites do Brasil. Outro oficial de orígem suíça, e já mencionado, foi o general de brigada José Jacob Baumann que exerceu o comando miltar na pro-

(11a.). - Reisebuch fuer tuetsche und waeltsche Land, Engelland, Hispanle, insel fuer Ameriqua und Afriqua, welliche insel una lender von namen hernach geschrieben stand. Angefangen im Jahr 1595. 
víncia de São Paulo nos anos de 1824 a 1826, isto é, numa época crítica e decisiva para o nosso país. Maior papel na história militar da nossa terra, desempenharam, todavia, os Resin, pai e filho. Carlos Resin pai nascera em 1801 (12) em Romain-môtier, no cantão de Vaud, e veio com os colonos de Nova Friburgo para o Brasil. Em 1824 assentou praça num dos corpos estrangeiros no Rio de Janeiro. Participou de tôdas as guerras exteriores assim como da pacificação interna do País. Salientou-se, todavia, principalmente na Guerra do Paraguai (1865-1870), onde pela primeira vez lutaram brasileiros de tôdas as províncias e de tôdas as procedências ombro a ombro pela integridade do Brasil, o que robusteceu exuberantemente o espírito de unidade nacional. Carlos Resin pai tomou parte nesta guerra como brigadeiro, primeiro como comandante da 10a. brigada e depois da 4a. divisão e da 1a. divisão de infantaria. Mereceu os mais altos louvores devido à sua coragem e os seus feitos - descritos por Schneider-Paranhos, Laurêncio Lago e outros historiadores - nas batalhas de Paisandú, onde foi gravemente ferido, na de Tuiutí, Humaitá e Campo Grande, sendo repetidamente elogiado e condecorado com o grau de comendador da Ordem de Cristo (1866) e da medalha de mérito militar (1869). O seu filho de mesmo nome, nascido em 1831 de mãe brasileira em Florianópolis, participou da campanha como capitão, sendo sucessivamente promovido por atos de bravura até alcançar o grau de coronel (1869). Foi nomeado cavaleiro da Ordem de Cristo, cavaleiro e comendador de São Bento de Avis e oficial da Ordem da Rosa e condecorado com diversas medalhas referentes a esta campanha. Faleceu em 1891 como um dos raros Marechais de Campo de então.

Para a evolução do patrimônio cultural nacional-brasileiro contribuiram não poucos naturalistas, cientistas e artistas de origem suíça em comum com outros estrangeiros, de preferência da região de língua germânica da Europa central. A maior obra científica a respeito do Brasil é considerada a Flora Brasiliensis com seus 40 tomos, projetada e dirigida pelo grande cientista alemão Carlos Filipe von Martius e entre seus 6 colaboradores botânicos encontra-

(12). - De acôrdo com as Informaçóes dos "Archives Cantonales" de Lausanne, Carlos Resin (pai) era filho llegitimo de Anne Sinnet Bofflens, de confissão reformada, sendo reconhecido pelo seu pai Henri Resín. A data de seu nascimento é o dia 5 de janeiro de 1801. Apesar de ter nascido na Suiça de língua francesa dominava perfeitamente $\circ$ alemáo que pronunciava com sotaque alemânico, nāo se sabendo com certeza qual a sua lingua materna. Servia no Rio como intérprete entre os oficials alembes e brasiletros e em Pôrto Alegre dava preferência aos círculos dos alemáes e seus descendentes, enviando os seus filhos à escola alemã do "Deutscher Hilfsverein" (Associaçáo Alemá de Mútuo Socôrro). Por outro lado pronunciava seu nome à moda francesa. Faleceu em 15-5-1886 no Rio Grande do Sul, e era casado com Claudina Mância de Laudicéta. 
mos 5 suíços. A obra Reisen durch Suedamerika, de Tschudi, que visitou o Brasil pela primeira vêz em 1859 , sendo nomeado no ano seguinte ministro de seu govêrno no nosso País já foi referida em outra passagem, mas deve ser mencionada aqui outra vez devido à sua significação como obra científica e naturalista. Dos 5 tomos, 4 são dedicados exclusivamente às províncias de Espírito Santo, Rio de Janeiro, Mato Grosso, São Paulo, Santa Catarina e Rio Grande do Sul, servindo de fonte ao famoso livro de Wappaeus.

Neste momento devemos destacar o famoso cientista suíço Luís Agassiz (13) que, financiado pelo mecenas americanos Thayer, visitou em companhia de sua espôsa e de seis pesquisadores, o Brasil em 1865-1866. Veio com êle ainda o desenhista Jacques Burckhardt que confeccionou 200 aquarelas de peixes brasileiros durante a permanência da expedição no Brasil. Er aAgassiz natural de Motier, no cantão de Friburgo, e americano naturalizado; estudara em Zurique, Heidelberg, Erlangen e Munique as ciências naturais, a medicina e a filosofia. Posteriormente foi professor de história natural em Neuchâtel (Neuenburg) na Suíça para aceitar em seguida a cátedra de zoologia comparada na Universidade de Harvard em Cambridge perto de Boston, nos Estados Unidos. Era adversário decidido do darwinismo e combatia a idéia da origem comum do mundo orgânico'e da variação dos animais. Chamou a atenção do mundo científico principalmente devido aos seus trabalhos sôbre os peixes fósseis assim como à sua teoria das geleiras e éra glacial que marcou época. Sua viagem através do Brasil levou-o no sul até o vale do Paraíba e Juiz de Fora, e no norte, seguindo a costa e todo o Rio Amazonas, até os limites do Brasil. Depois de navegar ainda por diversos afluentes do rio-mar voltou ao Rio de Janeiro e, conjuntamente com a espôsa, escreveu a obra de viagem $A$ Journey in Brazil (Boston, 1860) que Felix Vogeli verteu para o francês (Voyage au Brésil, Paris, 1869); em 1938 Edgar Süssekind de Mendonça publicou uma edição portuguêsa (Companhia Editôra Nacional, São Paulo). Agassiz ainda é o o autor das Conversaçốes scientificas sôbre o Amazonas feitas na sala do Colégio D. Pedro Il (Rio, 1866, 71 pág. ). Um dos seus com-

\footnotetext{
(13). - Seu nome completo era Jean Luis Adolphe Agassiz (nascido em 28-5-1807 e faleceu em 14-12-1873). Após seus estudos com o prof. Carl Friedrich Philipp von Martius que o estimulou para escrever o trabalho Pisces quae collegit et pingenda curavit Spix, Agassiz continuou a ocupar-se com os peixes brasileiros, publicando on the fossil fishes found by Mr. Gardner in the province of Ceara in the North of Brazil (in Philosophlcal Journal, Edinburgh, 1841) e Notice sur quelques poissons fossiles de la province de Ceard au Bresil ("Comptes rendus de l'Academle des Sciences", vol. 18, pág. 1007-15, 1844). Como as suas obras principals săo consideradas: Recherches sur les poissons fossiles, Monographie d'échinodermes vivants et fossils, Etudes sur les glaciers, Principes de zoologie, système glaciare.
} 
panheiros, Charles Frederick Hartt, tratou dos resultados geográficos e geológicos da expedição no seu livro Geology and Physical Geography of Brazil - Thayer Expeditions scientific results of a journey in Brasil by Luis Agassiz and his travelling companions (Boston, 1870), obra esta que também Edgar Süssekind de Mendonça, em colaboração com Elias Dolianiti, traduziu para o português (Companhia Editôra Nacional, São Paulo, 1941, 649 pág. ) .

O Visconde de Taunay, notável político e escritor brasileiro, menciona ainda os méritos de dois outros naturalistas suíços, Stephana Moricond, que visitou o Brasil de 1833 a 1846, descrevendo em seguida plantas novas, e o médico e botânico Dr. Schutel. Muito mais tarde, em 1925, veio ao Brasil, comissionado pela Universidade de Zurique o etnologo Heinrich Hintermann para estudaros índios bakairi e meinaco. Os mais notáveis cientistas de origem suíça no Brasil foram, entretanto, Lutz, Goeldi e Huber.

O bacteriólogo, biólogo e médico de moléstias tropicais Adolfo Lutz (1865 a 1940) foi um dos maiores cientistas de sua especialidade no Brasil. Nasceu em 1855 de pais suíços no Rio de Janeiro, passando, todavia, os anos de infância e mocidade em Berna, estudando em seguida em diversas Universidades da Europa e voltando só passageiramente em 1881 à sua terra natal. Em 1892, após uma estadia na Alemanha e em Honolulu, foi convidado pelo govêrno do Estado de São Paulo para organizar.o "Instituto Bacteriológico", primeiro centro da medicina experimental no País. Durante 16 anos dirigiu êste instituto que hoje se chama "Instituto Adolfo Lutz". Estudou Lutz aí e depois em Manguinhos junto com o famoso Osvaldo Cruz, durante decênios, os parasitas dos homens e animais. Publicou 212 trabalhos científicos de maior vulto estudos êstes de suma importância para os serviços de higiene, do combate ao tifo, da malária, das verminoses, da febre amarela etc. . Tirou também conclusões práticas para o combate a estas moléstias e arriscou a própria vida em favor da população do País, libertando-a no decorrer do tempo de muitas moléstias endêmicas. Deu êle ainda o primeiro passo para a fundação do famoso "Instituto Soroterápico de Butantan" em São Paulo para a produção de curativos eficazes contra a mordedura das cobras venenosas (14).

Outro naturalista notável que deixou o seu nome insolùvelmente ligado ao desenvolvimento das ciências no Brasil é o naturalista Emílio Augusto Goeldi (1859-1917), natural de Ennethbuehl perto de Sennwald, no cantão São Gal. Estudou em Jena, Lípsia e Berlim, com os mais afamados professôres da época. Em 1884 veio para o

(14). - A filha de Adolfo Lutz, Berta Lutz era uma das pioneiras do movimento feminino, lutando em prol de emancipação da mulher no Brasil. 
Brasil, comissionado para dirigir a seção de zoologia do Museu Nacional do Rio, sendo encarregado 10 anos depois com a direção do Museu Estadual em Belém do Pará. Imediatamente sob o equador criou um famoso lar das ciências naturais e etnológicas, o qual desde 1904 tem o nome do seu fundador, chamando-se "Museu Goeldi". Rodolfo Garcia denominou o "Museu Goeldi" com muito acêrto "o mostruário modêlo do grande vale amazônico". Confeccionou ainda mapas do imenso vale e auxiliou o Barão do Rio Branco na solução dos nossos problemas limítrofes. Com outros teuto-suíços como Jacó Huber Gottfried Hagemann (15) e C. Tchuemperli realizou expedições a todos os recantos da bacia amazônica. Publicou, como prof. da Universidade de Berna, numerosos trabalhos e monografias sôbre os assuntos de sua especialidade, isto é, as ciências naturais e a etnografia, assim como mapas geográficos do vale do Amazonas, enriquecendo desta maneira em escala considerável o patrimônio científico do País. Alguns anos depois de Goeldi voltar em 1907 à Suíça foi substituído por Jacó Huber (16) na direção do Museu. Huber nasceu em 1867, em Schleitheim, no cantão de Schaffhausen; estudou em diversas Universidades suíças e veio em 1895 a pedido de Goeldi para organizar o Jardim Botânico, ou seja a seção botânica do Museu $\epsilon$ um campo experimental. Empreendeu entre 1898 a 1904 numerosas viagens de estudo pelo Vale do Amazonas, tornando-se um dos mais destacados pesquisadores da flora do imenso território, descrevendo e descobrindo grande cópia de substâncias de valor econômico sôbre a nossa flora. Infelizmente houve após a gestão de Huber declínio considerável no nível científico do Museu que durante a direção de Goeldi empregara pelos fins do século XIX cêrca de 80 especialistas e auxiliares.

Afinal, queremos focalizar ainda alguns suíços no campo da arte. Em primeiro lugar mencionamos um poeta e comerciante suíço que vivia no Rio de Janeiro, Ferdinando Schmid, com o pseudônimo de Dranmor, natural de Berna, o qual foi festejado pelo nosso Carlos von Koseritz como sendo um grande lírico de língua alemã. De suas obras menciona o grande teuto-brasileiro a Valsa dos Demônios e o Requiem, que foi vertido para o português pela filha de Koseritz. O notável escritor brasileiro Visconde de Taunay chamou Dranmor

"poeta vigoroso apesar de seu pessimismo e caráter sombrio"

(15). - O dr. Gottfried Hagemann de Basiléla (falecido em-1947) era zoólogo e escreveu entre outros trabalhos: Die Vogelwelt der Insel Mexiana. (As aves da llha Mexiana; em: Zoologische Jahrbücher, Jena, 1907) .

(16) . - Huber, da mesma forma aliás que Goeldi, que possuia vastas plantaçóes de seringueiras, dedicou-se especialmente ao estudo do latex e das seringueiras num campo experimental, posteriormente denominado "Campo de Cultura Paraense Dr. Jacques Huber". 
cujo Hino a Morte mostraria belas passagens. Em todo o caso inseriu Bernardo Taveira Júnior em sua obra bilíngüe, Poesias Alemãs, algumas poesia dêste suíço estranho. Segundo Taunay teria publicado ainda estudos sôbre problemas bancários e de imigração.

No Rio de Janeiro nasceu em 1852 também Henrique Oswald, filho de um comerciante suíço natural de Neuchâtel (Neuenburg) que desde 1853 vivia em São Paulo e o qual originàriamente se chamava Oschwald ou Hoschwald. Desde 1868 Henrique Oswald estudou em Florença na Itália, terra de sua mãe, onde se casou e passou grande parte de sua vida. Seu professor era o maestro Buonamici, impregnado da música alemã de Hans von Bülow, Richard Wagner e Franz Liszt Tornou-se professor de piano no Instituto Musical de Florença e mais tarde, de 1911 em diante, fixou-se como professor particular no Rio de Janeiro, onde de 1903-1906 já fôra diretor do Instituto Nacional de Música. Oswald faleceu no Rio de Janeiro em 1931 e é considerado um dos maiores compositores brasileiros. Na sua obra

\footnotetext{
"se entrelaçam características musicais que são da escola alemã, da escola francesa e da escola italiana" (Luís Heitor).
}

Deixou numerosas composições, sendo precìpuamente apreciada a sua música de câmera, sinfônica e religiosa, influenciada em parte pelo romântico alemão Schumann. De suas obras mencionamos sòmente a sua famosa peça $I l$ neige com que conquistou em Paris entre 647 concorrentes o primeiro prêmio. Apesar de interessar-se pouco pela ópera, Henrique Oswald compôs três óperas: $L a$ eroce d'oro, Le fate e Il Néo, as quais, entretanto, não foram levadas a cena. Teve Henrique Oswald um filho de nome Carlos (1882195-) que se tornou famoso como pintor de assuntos sacros e históricos assim como gravador, fundando, em 1914, a Escola de Gravura à Água-Forte no Liceu de Arte e Ofícios no Rio de Janeiro.

Em Curitiba destacou-se outro músico e maestro de origem suíça, Leonardo Kessler (1882-1924), natural de Schiers, no cantão dos Grisões. Estudou em Estrasburgo e Paris e depois de dirigir o teatro de Flensburg veio com uma companhia de operetas ao Brasil, radicando-se na capital paranaense, onde fundou em 1912 o primeiro conservatório daquele Estado. Durante 12 anos contribuiu muito para o desenvolvimento da música no Brasil. Era professor apreciado, tendo alunos de envergadura como o compositor Brasílio Itibirê. Kessler deixou numerosas composições, das quais citamos a ópera Sidérea e Papúlio Innocentia.

Para terminar, queremos referir-nos ainda a outro notável descendente de suíços, o afamado filho de Emílio Augusto Goeldi: Os- 
waldo Goeldi (1895 a 1961). Nasceu no Rio de Janeiro, mas seguiu na idade de 8 anos para Berna, onde se criou. Mais tarde estudou as artes plásticas, voltando sòmente em 1919 ao Brasil. Era Oswaldo Goeldi mui raro exemplo de dedicação à arte. Tornou-se grande mestre e pioneiro da gravura moderna, principalmente da xilogravura no Brasil, deixando uma escola e muitos discípulos de valor. Goeldi é um dos maiores artistas brasileiros, internacionalmente reconhecido e distinguido com prêmios.

Não era a intenção do autor apresentar um relato exaustivo acêrca da contribuição suíça na formação da nação brasileira, mas tentar sim, indo ao encalço dos vestígios suíços na história do Brasil, dar uma impressão geral da valiosa e pacífica colaboração de um pequeno, porém, laborioso povo da Europa central, que o mundo, devido às suas virtudes cívicas, morais e espirituais, tanto admira .

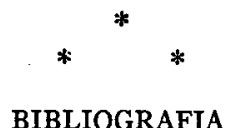

1. Para os suiços de língua alemã:

Oberacker (Jr.) Karl (Heinrich), Der deutsche Beitrag zum Aufbau der brasilianischen Nation, Editôra Herder, São Paulo, 1955.

Oberacker (Jr.) Carlos (H.), A contribuição teuta para a formação da nação brasileira, 2a. edição aumentada e melhorada em português, manuscrito ainda não publicado.

Queiroz, (Rachel de), Oswaldo Goeldi, artista brasileiro. "O Cruzeiro" de 11-3-61, pág. 130.

Silva (Quirina de). Oswaldo Goeldi, in "Diário de São Paulo" de 23-4-61. $O$ solitário e orgulhoso Goeldi, in "Visão" de 3-3-61.

2. Para os suíços de língua francesa e italiana:

Agassiz (Luís) e Elisabeth Cary Agassiz: Viagem ao Brasil (1865-1866), Trad. de Edgar Süssekind de Mendonça, Companhia Editôra Nacional, São Paulo, 1938.

Almeida (Renato), História da música brasileira, F. Briguiet, Rio, 1926.

Bandeira (Antônio Rangel), A composição pianistica no Brasil, in "Revista do Instituto do Livro", setembro 1957, pág. 91 e seg.

Boiteux (Henrique), Santa Catharina no exército, Revista Militar Brasileira, Vol. XXXV, 1936, Imprensa do Estado-Maior, 1937, pág. 219 e seg.

Heitor (Luís), 150 anos de música no Brasil (1800-1950), Livraria José Olympio Editôra, 1956.

Lago (Laurêncio), Os generais do exército brasileiro de 1860-1889, $3 .^{\circ}$ vol., Biblioteca Militar, Vol. LIX, Imprensa Nacional Rio de Janeiro, 1942.

Oswald (Carlos), Agua Forte, in "Vozes de Petrópolis", maio-junho, 1945, pág. 300 e seg. 
Mello-Leitão (C. de), História das expedições científicas no Brasil, Companhia Editôra Nacional, São Paulo, 1941.

Schneider (L.), A guerra da tríplice aliança, trad. de M. T. Alves Nogueira, anotado por Silva Paranhos, Edições Cultura, São Paulo, 1945.

Silva (Rodrigues da), Recordações da Campanha do Paraguai, Companhia Melhoramentos, São Paulo, (1924).

Taunay (Visconde de), Extrangeiros Ilustres e Prestimosos, RIHGB, tomo LVIII, 2a. parte, Rio de Janeiro, 1895 e seg. 